Brit. J. vener. Dis. (1957), 33, 172.

\title{
PRESENT PATTERN OF EARLY SYPHILIS IN THE MANCHESTER REGION*
}

\author{
BY \\ S. M. LAIRD \\ Regional Adviser to the Manchester Regional Hospital Board and Director, St. Luke's Clinic, Manchester
}

The recent reduction in the incidence of early acquired syphilis has resulted in a changed epidemiological pattern; formerly endemic, early syphilis now occurs only sporadically or in the form of small localized epidemics. This development presents interesting features and has been studied in the area of the Manchester Regional Hospital Board.

\section{Present Study}

The Manchester Regional Hospital Board area extends from Barrow-in-Furness in the north-west to Crewe in the south, a distance of about 120 miles $(193 \mathrm{Km}$.). The area is not more than 30 miles $(48 \mathrm{Km}$.) wide at any point and the population at the time of the 1951 Census was 4,398,306. More than 2,400,000 people live within a radius of 12 miles $(19 \mathrm{Km}$.) of Exchange Station, Manchester, and this is recognized as the most densely populated industrial area in Europe, not excluding the Ruhr. North of Preston the area is rural in character, with concentrations of population on the coast round Blackpool and Barrow-in-Furness, and in the vicinity of Lancaster. To the north of Manchester itself lie the industrial cotton towns, and to the south, in East Cheshire, the area is rural with a few towns engaged principally in engineering and light industries. Through the Manchester Ship Canal, Manchester and Salford have a world-wide maritime trade; in $1956,2,736$ ships $(3,338,755$ nett tonnage) used the Docks, and 1,698 of these ships $(2,858,439$ tons) were arrivals from foreign ports. The port at Preston has an active banana trade with the West Indies (1,585,767 tons of shipping in 1955 and 1,416,284 tons in 1956), and Barrow-in-Furness receives foreign crews which come to take over newly-built ships from its extensive dockyards. On

* Received for publication July 1, 1957. land, long distance road and railway transport traverse the area. The population of the city of Manchester is cosmopolitan, and the coloured section includes West Africans and West Indians.

The area is served by 22 V.D. clinics, seventeen in the peripheral towns and five in Manchester and Salford. Cases of acquired syphilis with infections of less than 1 year, reported by these clinics during the years 1948-56, are shown in Table I opposite. For comparison, the corresponding figures for England and Wales as a whole are shown in Table II opposite (Ministry of Health, 1956). As the population of the Manchester Regional Hospital Board area is about one-tenth of that of England and Wales, it will be noted that from 1953 the reduction of early acquired syphilis has proceeded relatively faster in the Manchester area.

\section{The Changing Pattern}

The marked and continuing reduction in the incidence of early acquired syphilis has made it easier, especially since 1952 , to discern the epidemiological links between cases, and in 1955 and - 1956 it became clear that the pattern of infection had changed. From an endemic infection, syphilis has now become sporadic, with some of these sporadic cases setting off small localized epidemics.

The Pattern in Manchester in 1955. - During June, 1955 , an increase was noted in the cases of primary syphilis in male civilians diagnosed at St. Luke's Clinic, Manchester (Table III opposite: Cases 6-12), and it seemed likely that some of these men who lived in Salford had a common source of infection. (Table III: Cases 7, 8, and 9). While the descriptions given were enough to suggest a common consort the identifying particulars were initially inadequate to 
TABLE I

CASES OF ACQUIRED SYPHILIS WITH INFECTIONS OF LESS THAN ONE YEAR, REPORTED BY THE V.D. CLINICS OF THE MANCHESTER REGIONAL HOSPITAL BOARD AREA

\begin{tabular}{|c|c|c|c|c|c|c|c|c|c|}
\hline \multirow{2}{*}{ Year } & \multicolumn{3}{|c|}{ Manchester Clinics } & \multicolumn{3}{|c|}{ Peripheral Clinics } & \multicolumn{3}{|c|}{ Whole Region } \\
\hline & Males & Females & Total & Males & Females & Total & Males & Females & Total \\
\hline $\begin{array}{l}1948 \\
1949 \\
1950 \\
1951 \\
1952 \\
1953 \\
1954 \\
1955 \\
1956\end{array}$ & $\begin{array}{r}620 \\
443 \\
257 \\
117 \\
43 \\
20 \\
24 \\
21 \\
7\end{array}$ & $\begin{array}{r}357 \\
255 \\
161 \\
66 \\
24 \\
13 \\
15 \\
12 . \\
4\end{array}$ & $\begin{array}{r}977 \\
698 \\
418 \\
183 \\
67 \\
33 \\
39 \\
33 \\
11\end{array}$ & $\begin{array}{r}403 \\
274 \\
145 \\
58 \\
29 \\
27 \\
6 \\
10 \\
22\end{array}$ & $\begin{array}{r}313 \\
193 \\
79 \\
48 \\
14 \\
13 \\
5 \\
4 \\
9\end{array}$ & $\begin{array}{r}716 \\
467 \\
224 \\
106 \\
43 \\
40 \\
11 \\
14 \\
31\end{array}$ & $\begin{array}{r}1,023 \\
717 \\
402 \\
175 \\
72 \\
47 \\
30 \\
31 \\
29\end{array}$ & $\begin{array}{r}670 \\
448 \\
240 \\
114 \\
38 \\
26 \\
20 \\
16 \\
13\end{array}$ & $\begin{array}{r}1,693 \\
1,165 \\
642 \\
289 \\
110 \\
73 \\
50 \\
47 \\
42\end{array}$ \\
\hline
\end{tabular}

TABLE II

CASES OF ACQUIRED SYPHILIS WITH INFECTIONS OF LESS THAN ONE YEAR, REPORTED BY THE V.D. CLINICS OF ENGLAND AND WALES*

\begin{tabular}{c|c|c|c}
\hline Year & Males & Females & Total \\
\hline 1948 & 6,603 & 4,034 & 10,637 \\
1949 & 4,392 & 2,420 & 6,812 \\
1950 & 2,678 & 1,465 & 4,143 \\
1951 & 1,498 & 774 & 2,272 \\
1952 & 891 & 462 & 1,353 \\
1953 & 755 & 319 & 1,074 \\
1954 & 600 & 208 & 808 \\
1955 & 609 & 228 & 837 \\
1956 & 587 & 257 & 844 \\
\hline
\end{tabular}

* Based on Table B, Appendix C of Part II of the Report of the Ministry of Health (1956).

TABLE III

DATE OF DIAGNOSIS OF MALE CASES OF ACQUIRED SYPHILIS WITH INFECTIONS OF LESS THAN ONE YEAR AT ST. LUKE'S CLINIC, MANCHESTER, DURING 1955

\begin{tabular}{|c|c|c|c|c|}
\hline $\begin{array}{l}\text { Case } \\
\text { No. }\end{array}$ & $\begin{array}{c}\text { Date of } \\
\text { Diagnosis }\end{array}$ & $\begin{array}{l}\text { Stage of } \\
\text { Syphilis }\end{array}$ & $\begin{array}{l}\text { Probable } \\
\text { Place of } \\
\text { Infection }\end{array}$ & Remarks \\
\hline $\begin{array}{l}1 \\
2\end{array}$ & $\begin{array}{l}\text { Apr. } 6 \\
\text { Apr. } 12\end{array}$ & $\begin{array}{l}\text { Primary } \\
\text { Early latent }\end{array}$ & $\begin{array}{l}\text { Manchester } \\
\text { Manchester }\end{array}$ & $\begin{array}{l}\text { Infected by prostitute } \\
\text { Wife found to have }\end{array}$ \\
\hline 3 & Apr. 13 & $\begin{array}{l}\text { Late } \\
\text { secondary }\end{array}$ & Unknown & Specific laryngitis \\
\hline 4 & Apr. 13 & Primary & Manchester & Infected by prostitute \\
\hline 5 & May 26 & Primary & Manchester & Infected by prostitute \\
\hline 6 & Jun. 2 & Primary & Salford & Prostitute near docks \\
\hline $\begin{array}{l}7 \\
8\end{array}$ & Jun. 8 & Primary & Salford & Not a prostitute \\
\hline $\begin{array}{l}8 \\
9\end{array}$ & Jun. 15 & Primary & Salford & Not a prostitute \\
\hline 10 & Jun. 21 & Primary & $\begin{array}{l}\text { Saltord } \\
\text { Manchester }\end{array}$ & $\begin{array}{l}\text { Not a prostitute } \\
\text { Prostitute }\end{array}$ \\
\hline 11 & Jun. 29 & & $\begin{array}{l}\text { Newcastle- } \\
\text { on-Tyne }\end{array}$ & $\begin{array}{l}\text { Lorry driver infected } \\
\text { by "lorry girl" }\end{array}$ \\
\hline 12 & Jun. 30 & Primary & Manchester & Prostitute \\
\hline $\begin{array}{l}13 \\
14\end{array}$ & Jul. 12 & Primary & Manchester & Prostitute \\
\hline 15 & Aug. 16 & Early latent & Unkn & $\begin{array}{l}\text { Not a prostitute } \\
\text { Homosexual }\end{array}$ \\
\hline 16 & Sept. 28 & Secondary & Salford & Infected in May. \\
\hline 17 & Oct. 13 & Secondary & Unknown & $\begin{array}{l}\text { Wife found to have } \\
\text { primary syphilis }\end{array}$ \\
\hline 18 & Oct. 14 & Primary & Manchester & $\begin{array}{l}\text { W if e de ve lo pe d } \\
\text { secondary syphilis, } \\
\text { March, } 1956\end{array}$ \\
\hline
\end{tabular}

permit the source of infection to be traced immediately. The three men were supplied with contact slips and urged to try and find the woman. On June 27, Case 9 reported that although he had not been able to see the woman he had found out her Christian name and her address. Through the Medical Officer of Health of Salford the woman was brought for examination later the same day; she was 23 years old, separated from her husband, and had late secondary-stage syphilis. Employed at a rubber works during the day, she picked up her male consorts outside public houses in the centre of the town in the evening, but neither haunted the dock area nor accepted money. Who infected her is unknown, but the rarity of civilian cases at the time suggests that her infection may have been by a seaman from the docks. It is believed that she infected five men (Table III: Cases 7, 8, 9, 14, and 16). Apart from Case 14 who subsequently infected his wife, no other cases apparently resulted.

In all the six male cases (Table III: Cases 1, 4, $5,10,12$, and 13) infected in Manchester during 1955 , the source of infection was a street prostitute. Three separate but nearby street locations were named by the six men, but their source or sources of infection could not be traced. In view of the relatively few cases of early syphilis seen in 1955 and 1956, it seems probable that only one infective prostitute was responsible. In Cases 2, 3, and 15 (Table III), the men deliberately or otherwise failed to provide information regarding the source of infection which probably occurred in all three cases during 1954. Case 18, a Jugoslav who subsequently infected his wife, denied extra-marital exposure, but it was found that a girl (No. 4983) who had attended St. Luke's Clinic on August 30, with primary syphilis, lived at the same address.

On November 12, 1955, after information was received from Southampton, a girl aged 20 years 
was examined and found to have secondary syphilis. A full-time prostitute operating from a licensed hotel and café adjacent to Salford docks, she also went aboard ships as opportunity offered. She was fined for the latter offence, and two of her associates, similarly apprehended, received prison sentences. It seems that she confined her activities to seamen and this is supported by the absence of infections in male civilians in Salford at the relevant time. It is probable that she was infected by a seafarer from overseas, and she may, have infected many seamen before being brought to treatment.

During 1955, therefore, infectious syphilis in Manchester occurred sporadically and infrequently, the sporadic case in a promiscuous female providing a small localized epidemic amongst men until she was traced and treated.

The Pattern in the Peripheral Clinics of the Region in 1956.-During 1954 and 1955, early syphilis in the male was diagnosed in only six and ten cases respectively in the seventeen peripheral clinics of the Region. In 1956, however, these peripheral clinics had 22 male cases of early syphilis; for the first time, therefore, early syphilis had become more prevalent in the periphery of the Region than in Manchester itself (Table I). Some eighteen of these 22 male cases came from two areas: Preston (twelve cases), and Blackburn and Burnley (six cases).

At Preston, four cases were diagnosed in seamen infected in the West Indies, two civilians were infected in London and Southampton respectively, and in one case with early latent syphilis the place of infection was uncertain (Table IV). Three male cases were definitely infected by the one woman (No. 9409) in Preston, and it is likely but not certain that the remaining two male cases were also infected by her. This woman, aged 37 years, had had hysterectomy performed, and when traced on October 2, 1956, was found to have late secondary syphilis.

In April, 1956, notification was received from Bristol that a Burnley woman was responsible for a male case of primary syphilis. This woman was traced and found to have secondary syphilis; she was awaiting an appointment to see the dermatologist! This woman admitted to two contacts in Burnley and both were found to have primary syphilis. Three weeks later a man in Blackburn with primary syphilis described the Burnley woman and identified her from a photograph shown to him. Another female consort of this Blackburn man developed a chancre six weeks later. The Burnley woman, who was thus responsible for the infection
TABLE IV

DATE OF DIAGNOSIS OF MALE CASES OF ACQUIRED SYPHILIS WITH INFECTIONS OF LESS THAN ONE YEAR, SEEN AT PRESTON DURING 1956

\begin{tabular}{|c|c|c|c|c|}
\hline $\begin{array}{l}\text { Case } \\
\text { No. }\end{array}$ & $\begin{array}{l}\text { Date of } \\
\text { Diagnosis }\end{array}$ & $\begin{array}{l}\text { Stage of } \\
\text { Syphilis }\end{array}$ & $\begin{array}{l}\text { Probable } \\
\text { Place of } \\
\text { Infection }\end{array}$ & Remarks \\
\hline 1524 & Feb. 14 & Primary & West Indies & Seaman infected by \\
\hline 1526 & Feb. 16 & Primary & West Indies & $\begin{array}{l}\text { Seaman infected by } \\
\text { prostitute }\end{array}$ \\
\hline 1630 & May 1 & Early latent & West Indies & $\begin{array}{l}\text { Seaman infected by } \\
\text { prostitute }\end{array}$ \\
\hline $\begin{array}{l}1774 \\
1792\end{array}$ & $\begin{array}{l}\text { Aug. } 3 \\
\text { Aug. } 15\end{array}$ & $\begin{array}{l}\text { Primary } \\
\text { Primary }\end{array}$ & $\begin{array}{l}\text { Preston } \\
\text { South- } \\
\text { ampton }\end{array}$ & $\begin{array}{l}\text { Infected by } 9409 \\
\text { Civilian. Consort } \\
\text { not a prostitute }\end{array}$ \\
\hline 1816 & Aug. 22 & Primary & Preston & $\begin{array}{l}\text { Probably infected by } \\
9409\end{array}$ \\
\hline 1836 & Aug. 29 & Primary & London & $\begin{array}{l}\text { Civilian. Infected by } \\
\text { prostitute. }\end{array}$ \\
\hline 1844 & Sept. 5 & Primary & Preston & $\begin{array}{l}\text { Probably infected by } \\
9409\end{array}$ \\
\hline $\begin{array}{l}1888 \\
2020\end{array}$ & $\begin{array}{l}\text { Sept. } 26 \\
\text { Nov. } 30\end{array}$ & $\begin{array}{l}\text { Primary } \\
\text { Primary }\end{array}$ & $\begin{array}{l}\text { Preston } \\
\text { West Indies }\end{array}$ & $\begin{array}{l}\text { Infected by } 9400 \\
\text { Seaman infected by }\end{array}$ \\
\hline $\begin{array}{l}2042 \\
2074\end{array}$ & $\begin{array}{l}\text { Dec. } 7 \\
\text { Dec. } 28\end{array}$ & $\begin{array}{l}\text { Secondary } \\
\text { Early latent }\end{array}$ & $\begin{array}{l}\text { Preston } \\
\text { Uncertain }\end{array}$ & Infected by 9409 \\
\hline
\end{tabular}

of four men directly and one woman indirectly, had herself been infected in Blackpool by a holidaymaker (Figure).

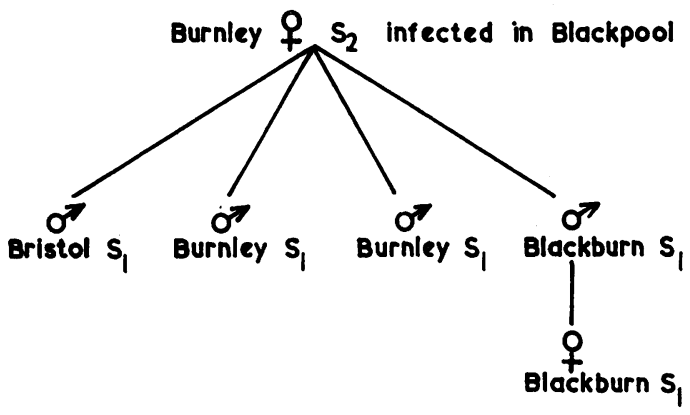

S. Primary syphilis

$S_{2}$ Secondary syphilis

FigURE.-Pattern of spread of infection from a single source.

In addition to this localized epidemic, there were the following sporadic cases: one male case of urethral chancre in Blackburn whose alleged contact was not infected, but whose aunt with whom he lived was found to have early latent syphilis; one male with primary syphilis in Burnley whose local consort proved to have secondary syphilis; and one man in Burnley with secondary syphilis who had been infected by a prostitute in London.

\section{Conclusions}

The marked decline in infectious syphilis has made it easier to trace the epidemiological chains 
of infection between cases. In the past 2 years syphilis, previously endemic, has become a sporadic infection, some sporadic cases leading to minor localized epidemics. Infectious syphilis has hitherto been regarded as an infection of the large city, especially where the city is a seaport and has a cosmopolitan population; with the changed pattern of syphilitic infection noted in the area of the Manchester Regional Hospital Board during 1956 this traditional situation has been reversed.

\section{Summary}

The epidemiology of infectious syphilis during 1955 and 1956 has been studied in the area of the Manchester Regional Hospital Board. In this area syphilis has ceased to be endemic and is now found only in sporadic cases, some of which, however, may give rise to small localized epidemics. This changing pattern of infection suggests some reconsideration of the traditional view that syphilis is predominantly an infection of the major cities and seaports; in the Manchester Region during 1956 the position was actually reversed.

I wish to thank the consultant venereologists throughout the Region for generously supplying the detailed information about their cases.

\section{REFERENCE}

Ministry of Health (1956). Table B, Appendix C, Part II of Report for year ended December 31 st, 1955 . Ćmnd. 16, p. 255, H.M.S.O., London. 